\title{
RAPD ANALYSIS OF LINES DERIVED FROM INTERSPECIFIC CROSS Helianthus annuus L. $\times$ Helianthus salicifolius
}

\author{
Encheva, J. ${ }^{*}$, Köhler, $\mathrm{H}^{2}$ and Friedt, W. ${ }^{2}$ \\ ${ }^{1}$ Dobroudja Agricultural Institute, General Toshevo 9520, Bulgaria \\ 2 Institute of Plant Growing and Plant Protection, Giesen, Germany
}

Received: October 16, 2012

Accepted: December 01, 2012

\begin{abstract}
SUMMARY
Interspecific hybridization is frequently restricted by genetic cross incompatibilities, genetic distances and different ploidy levels. To overcome this incompatibility a direct organogenesis method has been used successfully. Different molecular methods have been used for verification of success interspecific and intergeneric crosses. It could be demonstrated by results of RAPD fingerprinting that interspecific hybridization is also a valuable tool for broadening genetic variability in sunflower. The successful hybridization between $(H$. annuus (cv. Albena) $\times H$. salisifolius) was achieved. In total 21 RAPD primers ( $10 \mathrm{bp}$ ) length were used for the characterization of interspecific progenies. We were able to demonstrate that RAPD could be used for characterization of interspecific progenies in sunflower at a late stage of selection $\left(F_{9}\right)$. It was possible to discriminate between the $H$. annuus parents and their progenies, where an increased genetic variability was detected. Results of UPGMA cluster analysis confirmed the hybrid nature of the interspecific lines and showed that hybrid progenies which originate in the same cross combination formed specific cluster each, i.e., distinct genetic pools.
\end{abstract}

Key words: sunflower, Helianthus annuus L., H. salicifolius, interspecific hybridization, RAPD analysis

\section{INTRODUCTION}

The genus Helianthus consists of 49 species, 13 annual and 36 perennial ones with different ploidy levels (Schilling and Heiser, 1981). These different ploidy levels create a lot of difficulties for taxonomists to define "pure" species. While introgression and hybridization make identifying and classifying species of the genus difficult, this genetic diversity is important as a potential source of genes for the improvement of cultivated sunflower (Seiler et al., 1992).

* Corresponding author: e-mail: July_262002@yahoo.com; July_26@abv.bg 
Knowledge of genetic relationships in novel breeding material which derives from interspecific and intergeneric crosses is essential for breeders. Particularly molecular techniques developed recently are highly specific tools to differentiate between and classify genotypes. These modern tools complete the more classical methods based mainly on morphological, biochemical and physiological traits and allow the determination of the degree of genetic similarity within populations of a species and related genera.

Altogether, 33 different hybrid combinations between wild and cultivated sunflower were realized by Kräuter et al., 1991 via the "embryo rescue" technique. The authors applied RFLP analysis for rapid and safe characterization in early developmental stages of the hybrids. RAPD technique was used to confirm the hybrid origin of $H$. annuus $\times H$. maximiliani and $H$. annuus $\times H$. giganteus crosses (Henn et al.,1998). RFLP markers were successfully used for the characterization of two interspecific hybrids, $H$. annuus $\left(\mathrm{F}_{1}\right.$ cultivated hybrid $) \times H$. mollis and $H$. orgyalis, one intergeneric cross between $H$. annuus $\times$ Viguera (Faure et al., 1998). The AP-PCR fingerprinting techniques was applied for the characterization of interspecific hybrid progeny between $H$. annuus and wild species $H$. mollis, $H$. decapetalus, H. giganteus, H. maximiliani Schrader and H. tuberosus (Köhler and Friedt, 1999). Molecular markers (RAPD) were used to estimate what portion of the parental species genome was present in the interspecific hybrids of the $F_{1}$ and $\mathrm{BC}_{1} \mathrm{~F}_{1}$ generations (Atlagić et al., 2003). The molecular RAPD analysis carried out on stable self-pollinated lines confirmed the hybrid nature of the breeding materials obtained from the cross between $H$. annuus $\times H$. tuberosus (Encheva et al., 2004). RAPD markers were employed to study the genetic relationship between cultivated sunflower and selected wild sunflower species (Mohan and Seetharam, 2005). Polymorphism of $H$. annuus, $H$. pauciflorus ssp. subrhomboideus and their $\mathrm{F}_{1}$ hybrids was studied by RAPD. The results showed introgression of the subspecies Subrhomboideusin in the hybrid progeny (Hristova-Cherbadzi et al., 2007). Using RAPD markers Anisimova et al., 2009 showed that the IL genome produced from sunflower interspecific hybrids is characterized by instability even after long-term inbreeding (in generations $\mathrm{F}_{8}-\mathrm{F}_{12}$ ). The successful hybridization between $\mathrm{H}$. rigidus and $H$. annuus was confirmed with RAPD markers (Panković, 2007). RFLP markers in $21 \mathrm{BC}_{1}$ plants from the cross $H$. annuus $\times H$. mollis showed that some progenies display 6 to $44 \%$ of introgression from $H$. mollis (Breton et al., 2010).

Molecular techniques, particularly RAPD, provide a promising approach for the identification of interspecific and intergeneric hybrids and their progenies derived either by conventional breeding or by biotechnological methods.

The aim of our study was to confirm the hybrid nature of the interspecific crosses ( $F_{9}$ progeny) between $H$. annuus (cv. Albena) $\times H$. salicifolius via RAPD technique. 


\section{MATERIAL AND METHODS}

\section{Plant material}

Inbred restorer lines R 107, R 110, R 114 and R 120 in the $F_{9}$ generation derived from the interspecific hybrid $H$. annuus (hybrid Albena) $\times H$. salicifolius by direct organogenesis method were used to analyze the genetic variation.

\section{DNA extraction}

RAPD analysis was carried out using genomic DNA extracted by a method according to Doyle and Doyle (1990) with some modifications. Sunflower leaf tissue was ground to a fine powder in liquid nitrogen. The frozen powder $(2.5 \mathrm{~g})$ was transferred to $15 \mathrm{ml}$ hot hexadecyltrimethylammonium bromide (CTAB) extraction buffer [( $2 \%$ CTAB, $100 \mathrm{mM}$ Tris $\mathrm{HCl}$ (pH 8.0), $20 \mathrm{mM}$ EDTA, $1 \% \mathrm{Na}_{2} \mathrm{~S}_{2} \mathrm{O}_{5}, 0.2 \% \beta$ mercaptoethanol)] and incubated at $65^{\circ} \mathrm{C}$ for $30 \mathrm{~min}$. with occasional shaking. An equal volume of chloroform : isoamylalcohol (24:1 v/v) was added and mixed by inversion, then centrifuged at $6000 \mathrm{rpm}, 4^{\circ} \mathrm{C}$ for $10 \mathrm{~min}$. The aqueous phase was transferred to a fresh tube and re-extracted with an equal volume of chloroform : isoamylalcohol $(24: 1 \mathrm{v} / \mathrm{v})$ and centrifuging at $5000 \mathrm{rpm}, 4^{\circ} \mathrm{C}$ for 10 min. The aqueous phase was removed and transferred to a fresh tube again and precipitated in $1.0 \mathrm{ml}$ ammonium acetate $(10 \mathrm{M}), 1.0 \mathrm{ml}$ sodium acetate $(3 \mathrm{M}, \mathrm{pH}$ 5.5 ) and 2/3 VT 2-propanol $\left(4^{\circ} \mathrm{C}\right)$. Lastly, the precipitated DNA was dried and resuspended in TE buffer ( $10 \mathrm{mM}$ Tris $\mathrm{HCl}(\mathrm{pH}$ 8.0) and 1 mM EDTA, $\mathrm{pH}$ 8.0). After treatment with RNase, the DNA concentration was measured by using a flourometer (Model TKO 100, Hoefer Scientific Instruments, Serva, Germany).

\section{DNA amplification}

Short 21 RAPD primers (10 bp) were utilized for the amplification of random DNA sequences (Table 1). Primer selection was based on the information content, clarity and reproducibility of banding patterns. Amplifications were carried out in a $20 \mu \mathrm{l}$ volume containing: 1.5 units polymerase Stoffel fragment "Goldstar" (Eurogentec), $1 \times$ reaction buffer, $6 \mathrm{mM} \mathrm{MgCl}_{2}, 0.4 \mathrm{mM}$ each of dATP, dCTP, dGTP and dTTP, $25 \mathrm{ng}$ of template DNA, $10 \times$ Stoffel buffer, add $20 \mu \mathrm{H}_{2} \mathrm{O}$ and $0.3 \mu \mathrm{M}$ of primer. The amplifications were performed using a Thermal cycle 9600 . The thermal cycle was programmed for a first denaturation step of $4 \mathrm{~min}$. at $94^{\circ} \mathrm{C}$ followed by 45 cycles of $2 \mathrm{~min}$. at $94^{\circ} \mathrm{C}, 1 \mathrm{~min}$. at annealing temperature $36^{\circ} \mathrm{C}$ and $2 \mathrm{~min}$. extension step at $72^{\circ} \mathrm{C}$.

Amplification products were resolved by gel electrophoresis in $2 \%$ agarose in 0.5 TBE (89 mM Tris pH 8.0, $89 \mathrm{mM}$ boric acid and 0.5 M EDTA), stained with etidiumbromide and visualized on a UV screen.

Molecular sizes of the amplification products were estimated by using a $100 \mathrm{bp}$ DNA ladder (Gibco BRL, Life Technologies). 


\section{Analysis of amplification profiles}

Amplification profiles of Helianthus genotypes were compared with each other and bands of DNA fragments were scored as present (1) or absent (0). The computer program "RFLPscan", (Scanalytics, Billerica, MA, USA) was used to estimate the data for all the 21 primers.

The similarity was then analyzed on the basis of the number of shared amplification products according to Nei and Li (1979). A dendrogram based on similarity coefficients was generated with the programme "NTSys" (Version 1.80, Exeter Software, Setauket, NY, USA) by using the unweighted pair group method of arithmetic means (UPGMA).

Table 1: List of the primers used to characterize interspecific progenies in Helianthus

\begin{tabular}{|c|c|c|}
\hline Primer & Primer sequence $\left(5^{`}-3^{`}\right)$ & $\mathrm{Ta}^{*}$ \\
\hline$A-12$ & $5^{`}$ TCG GCG ATA G 3 ` & 36 \\
\hline$A-16$ & $5^{`} \mathrm{AGC}$ CAG CGA A $3^{`}$ & 36 \\
\hline$A E-01$ & $5^{`}$ TGA GGG CCG T 3` & 36 \\
\hline AE-03 & $5^{`}$ CAT AGA GCG G $3^{`}$ & 36 \\
\hline $\mathrm{AH}-15$ & $5^{`}$ CTA CAG CGA G $3^{`}$ & 36 \\
\hline AJ -19 & $5^{`}$ ACA GTG GCC T $3^{`}$ & 36 \\
\hline AJ-20 & $5^{`}$ ACA CGT GGT C $3^{\prime}$ & 36 \\
\hline AK-05 & $5^{`}$ GAT GGC AGT C $3^{`}$ & 36 \\
\hline AK-08 & $5^{`} \mathrm{CCG}$ AAG GGT G $3^{`}$ & 36 \\
\hline AO-14 & $5^{`}$ CTA CTG GGG T $3^{`}$ & 36 \\
\hline AO-18 & $5^{`}$ GGG AGC GCT T $3{ }^{`}$ & 36 \\
\hline AO-20 & $5^{`}$ GGC TTGCCT G $3{ }^{\prime}$ & 36 \\
\hline AP-04 & $5^{`}$ CTC TTG GGC T $3{ }^{\prime}$ & 36 \\
\hline AP-05 & $5^{`}$ GAC TTC AGG G $3^{`}$ & 36 \\
\hline AS - 12 & $5^{`}$ TGA CCA GGC A $3{ }^{`}$ & 36 \\
\hline AT-12 & $5^{`}$ CTG CCT AGC C $3^{\prime}$ & 36 \\
\hline AV -10 & $5^{`}$ ACC CCT GGC A $3^{`}$ & 36 \\
\hline AW -17 & $5^{`}$ TGC TGC TGC C $3{ }^{`}$ & 36 \\
\hline AW -18 & $5^{`}$ GGC GCA ACT G $3^{`}$ & 36 \\
\hline AW -19 & $5^{`}$ GGA CAC AGA G $3{ }^{`}$ & 36 \\
\hline W-04 & $5^{`} \mathrm{CAG} A A G$ CGG A $3{ }^{\prime}$ & 36 \\
\hline
\end{tabular}

$\mathrm{Ta}^{\star}$ : annealing temperature actually used

\section{RESULTS AND DISCUSSION}

Inbred restorer lines R 107, R 110, R 114 and R 120 derived from the interspecific hybrid $H$. annuus (cv. Albena) $\times H$. salicifolius by direct organogenesis method were used to analyze the genetic variation.

The RAPD primers generated a higher degree of polymorphism in sunflower and resulted in distinct and clear patterns. Analyses were carried out on those fragments that were well visible. The comparison of the amplification profiles of $\mathrm{F}_{9}$ plants and parents was based on the presence or absence of fragments. 


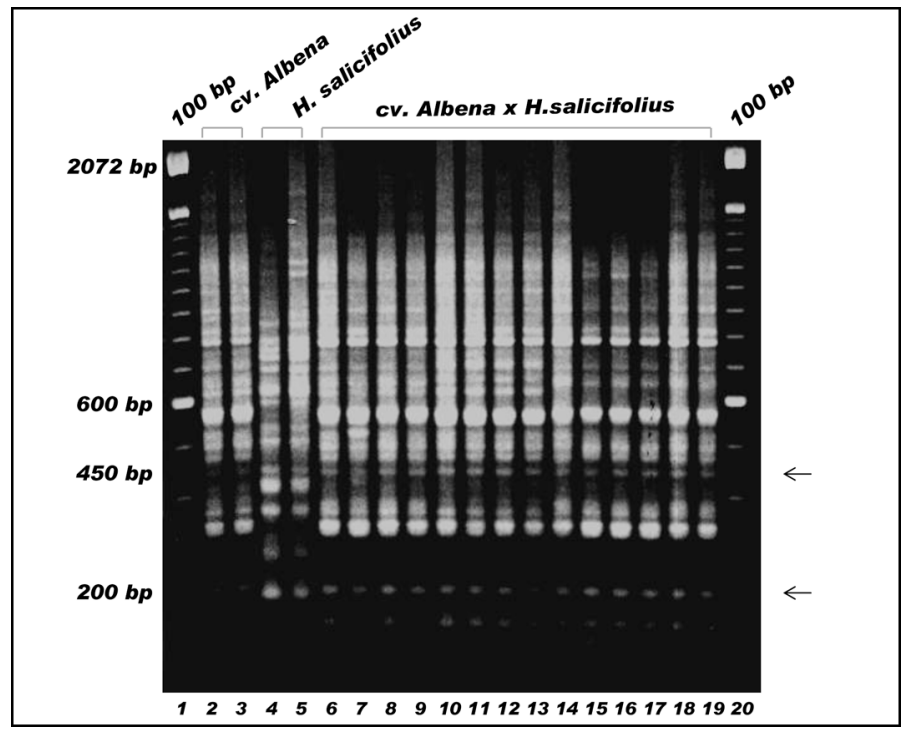

Figure 1: Genetic profile of interspecific sunflower hybrids progenies (Helianthus annuus $\times$ $H$. salicifolius) based on primer OPAE-01. Lines 2 and 3: maternal parent (cv. Albena). Lines 4-5: paternal parent (H. salicifolius); Lines 6-19 interspecific hybrid progenies: 6-9-line R 110; 10-13-line R 120; 14-15-line R 107 and 16-19line R 114; Lines 1 and 20: 100 bp ladder. (Gibco BRL, Life Sciense Technology)

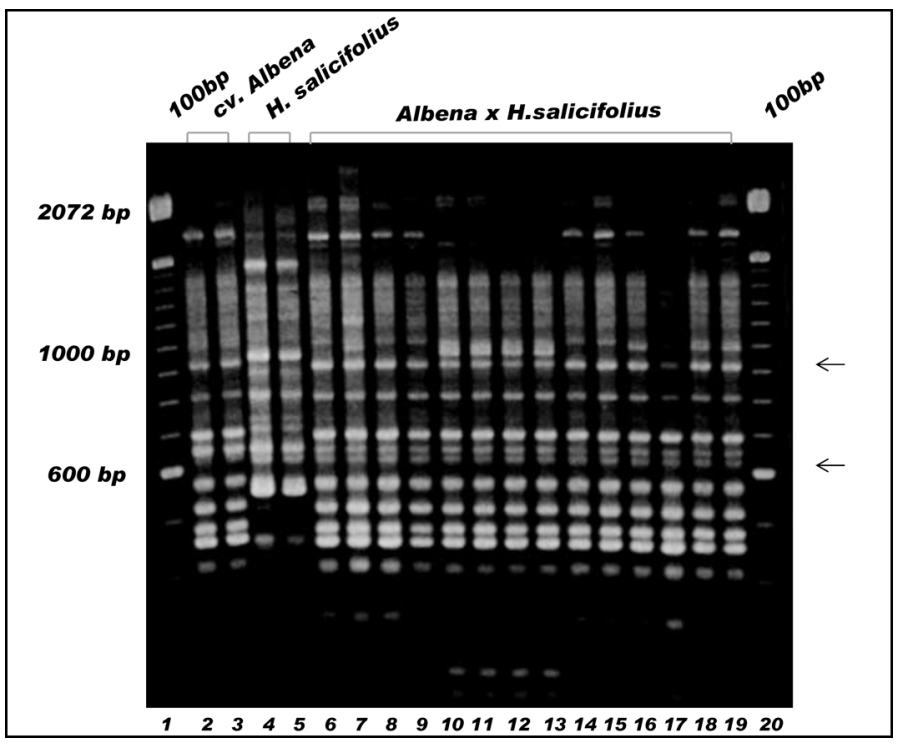

Figure 2: Genetic profile of interspecific sunflower hybrids progenies (Helianthus annuus $\times$ $H$. salicifolius) based on primer OPAS-12. Lines 2 and 3: maternal parent ( $c v$. Albena). Lines 4-5: paternal parent (H. salicifolius); Lines 6-19 interspecific hybrid progenies: 6-9-line R 110; 10-13-line R 120; 14-15-line R 107 and 16-19line R 114; Lines 1 and 20: 100 bp ladder. (Gibco BRL, Life Sciense Technology) 
In total twenty one (10 base) primers with random sequences were applied to characterize DNA sequences of the lines R 107, R 110, R 114 and R 120 obtained from the interspecific cross. Two of the total of 21 primers used (OPAE-01 and OPAS-12) gave polymorphic products for the interspecific hybrid progeny, which were missing in the cultivated sunflower. The two primers amplified polymorphic fragments for all of the studied hybrid progenies. The primer OPAS-12 gave polymorphic products for line R 120 only.

In our study RAPD fingerprint obtained through primer OPAE-01 revealed considerable variation in the hybrid progenies. Figure 1 demonstrates some fragments in the interspecific hybrid progenies with a size of $200 \mathrm{bp}$ and $450 \mathrm{bp}$ which were specific for the genotype of the wild species $H$. salicifolius, only. There were also bands specific for the genotypes of cultivated sunflower.

Genetic profile based on primer OPAS-12 (Figure 2) showed bands with sizes $630 \mathrm{bp}$ and $950 \mathrm{bp}$ at hybrid progenies which were typical for wild $H$. salicifolius. Bands with size $630 \mathrm{bp}$ were common for all four hybrid progenies, while band 950 bp was specific for line R 120 only.

These DNA fragments obtained with primers OPAE-01 and OPAS-12 indicate a probable introgression from $H$. salicifolius DNA into the obtained inbred lines. In spite of the fact that the lines investigated were selfed for nine generations, proportions of the wild alien genome(s) are still detectable and are highly specific for the $H$. salicifolius used for the interspecific hybridization.

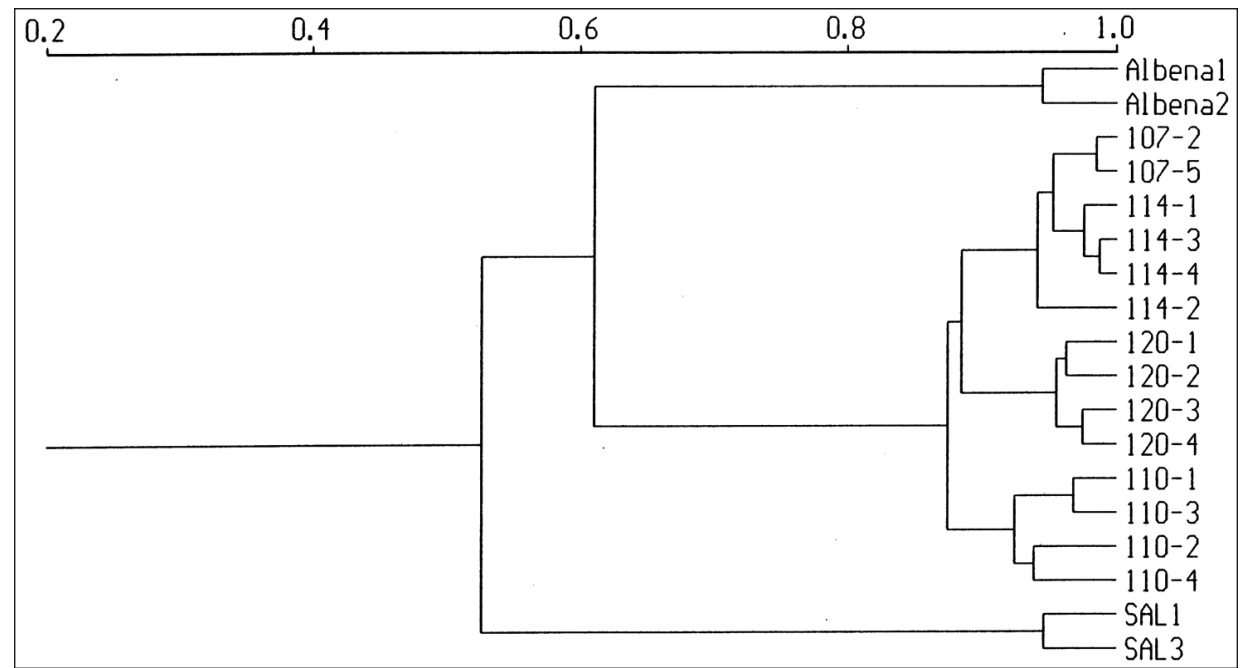

Figure 3: Dendrogram constructed from a matrix of RAPD-marker based genetic similarities between $H$. annuus (cv. Albena), H. salicifolius and interspecific hybrids

By using the similarity coefficient of Nei and Li, 1979 a dendrogram was generated through UPGMA analysis with the aim to determine the genetic distance of the studied genotypes. The cluster analysis (Figure 3) distinguished three main groups 
(the interspecific progenies, cv. Albena and $H$. salicifolius). The constructed scheme revealed that the species $H$. salicifolius was distinctly separated from the other genotypes in the study (cv. Albena and the interspecific lines), forming their own genetic pool.

Based on the RAPD data the cluster analysis distinguished a main cluster including all interspecific progenies (R 107, R 110, R 114, and R 120) divided into several smaller groups. Lines R 107 and R 114 demonstrated the highest degree of similarity and were located at considerable distances from genotypes R 120 and R 110. The newly released line $\mathrm{R} 107$ possessed a higher degree of homogeneity than R 114, R 120 and R 110. All hybrid progenies were placed at considerable distance from the cultivated parent (cv. Albena), but the degree of similarity between them was higher than with the wild parent $H$. salicifolius.

There are just a few publications on the use of molecular markers for identification of $\mathrm{F}_{1}$ interspecific and intergeneric sunflower hybrids and their progenies. While Kräuter et al. (1991) and Faure et al. (1998) have used RFLP markers, Köhler et al. (1999) have applied AP-PCR technique.

In our study we also used short 10 base RAPD primers. The interspecific cross (H. annuus (cv. Albena) $\times H$. salicifolius) was obtained according to the method of direct organogenesis (Encheva et al., 1992). The available literature does not provide data on the obtaining of these hybrid combinations with that method. The cluster and coordinates analysis confirmed the hybrid nature of the interspecific progenies. Cultivated sunflower (cv. Albena), the $H$. salicifolius and their hybrid lines were clearly distinguishable. From the constructed scheme (Figure 3 ) it is evident that $H$. salicifolius and cultivated sunflower did not form clusters with any of the hybrid progenies. The discriminating power of molecular markers, in comparison to morphological and biochemical markers is higher, therefore they are generally superior for the assessment of genetic diversity due to better sensitivity and efficiency (Lamkey and Lee, 1993).

The wild Helianthus species are a potential source of genes for resistance to diseases and pests and of considerable variability for most agronomic traits and qualities of seed (Thomson et al., 1981) and could be included in interspecific and intergeneric crosses for increasing genetic variability in cultivated sunflower (Seiler, 1992, 1997; Škorić and Rajčan, 1992; Škorić et al., 1995; Köhler et al., 1997; Thomson et al., 1981).

In our study RAPD analysis indicated increased genetic variation in hybrid progenies. This genetic variation is a valuable source of resistance to diseases, parasites and improved agronomic indices. The phytopathological evaluation of parental forms and the obtained hybrid progenies (Encheva et al., 2006) showed complete resistance to Phomopsis (line R 114) and to Alternaria (line R 120). This resistance probably comes from the wild species $H$. salicifolius, which, according to the investigation of Christov, $(1990,1996)$ and Christov et al. (1996) has shown 
complete resistance to Phomopsis. Among the sources of resistance to Phomopsis and Alternaria, Škorić, 1987 pointed out $H$. salicifolius.

As a result of interspecific hybridization, line R 107 was developed, which showed $100 \%$ resistance to parasite Orobanche cumana Wallr. against artificial infection background. The resistance of the line $\mathrm{R} 107$ comes from the wild $\mathrm{H}$. salicifolius, which according to Christov et al. (1996) has complete resistance to the parasite under both field and laboratory conditions. The female form (cv. Albena) in the interspecific cross is, on its part, susceptible to the diseases and parasite mentioned above.

Instead of resistance, the new lines R 107 and R 114 were characterized by positive transgression in comparison to parental forms for traits such as number of branches, length of branches and diameter of branch head (Encheva and Christov, 2006). The negative transgression was establish for lines R 107, R 114 and R 120 for the indexes plant height, number of leaves and vegetation period.

\section{CONCLUSION}

We have successfully applied molecular markers to investigate diversity of sunflower cultivar, wild sunflower species, as well as to identify interspecies hybrids.

The results confirm that polymorphism occurred in the amplification PCR profiles of $H$. annuus, $H$. salicifolius and $H$. annuus $\times H$. salicifolius, i.e., the RAPD analysis confirmed the hybrid nature of the $\mathrm{F}_{9}$ material obtained from interspecific cross. RAPD markers indicated also a possible introgression of wild genome portions into the obtained interspecific hybrid progenies

Our data confirmed the conclusion drawn by Köhler et al. (1999) that the lines which originate from the same interspecific cross form their specific cluster, i.e., the related lines could be grouped into a separate gene pool.

We were able to demonstrate that RAPD could be used for characterization of interspecific progenies in sunflower at a late stage of selection $\left(\mathrm{F}_{9}\right)$ in which an increased genetic variation was discovered. This genetic variation is a valuable source of resistance to diseases, parasites and improved agronomic indices.

The interspecific hybrids provide valuable initial material to enlarge genetic variation in sunflower and genetic markers could help the breeders to characterize this new material.

\section{REFERENCES}

Anisimova, I.N., Tumanova, L.G., Gavrilova, V.A., Diagileva, A.V., Pasha, L.I., Mitin, V.A. and Timofeeva, G.I., 2009. Genomic instability in sunflower interspecific hybrids. Genetika 45(8): 1067-1077.

Atlagić, J., Panković, D. and Pekanović, A., 2003. Backcrosses in interspecific hybridization in sunflower. Genetika 35(3): 187-197.

Breton, C., Serieys, H. and Berville, A., 2010. Gene transfer from wild Helianthus to sunflower: topicalities and limits. Oleagineux, Corps Gras, Lipides 17(2): 104-114. 
Christov, M., 1990. Study on the wild species from genus Helianthus with a view of their use in sunflower breeding. Ph.D Thesis, Sofia (Bg): p. 208.

Christov, M., 1996. Characterization of wild Helianthus species as sources of new features for sunflower breeding. In: P.D.S. Caligari \& D.J.N. Hind (eds). Compositae. Biology and Utilization. Proceedings of the International Compositae Conference, Kew, 1994. (D.J.N. Hind, Editor-in-Chief), Vol. 2: 547-570. Royal Botanic Gardens, Kew, 2: 603-615.

Christov, M., Shindrova, P. and Encheva, V., 1996. Transfer of new characters from wild Helianths species to cultivated sunflower. Gent. a Selecht. 32(4): 275-286.

Christova-Cherbadzi, M., Atanasova, R., Batchvarova, R., Christov, M. and Ivanova, I., 2007. Characterization of hybrids between $H$. annuus L. and the subspecies subrhomboideus (Rydberg) Heiser of perennial hexaploid $H$. pauciflorus. Helia 30(47): 37-50.

Doyle, J.F. and Doyle, J.L., 1990. Isolation of plant DNA from fresh tissue. Focus 12: 13-15.

Encheva, J., Christov, M. and Ivanov, P., 1992. Use of direct organogenesis in vitro from immature embryos of interspecific and intergeneric hybrids of Helianthus annuus L. Proceedings of the $13^{\text {th }}$ International Sunflower Conference, Pisa (Italy), 7-11 September, Vol. II: 1455-1460.

Encheva, J., Christov, M., Kohler, H., Shindrova, P., Encheva, V. and Friedt, W., 2004. Interspecific hybrids between Helianthus annuus and $H$. tuberosus: RAPD analysis, disease resistance, combining ability. B.J.A.S. 10(2): 169-175.

Encheva, J. and Christov, M., 2006. Interspecific hybridization between cultural sunflower Helianthus annuus L. and Helianthus salicifolius L.-morphological and biochemical characterization. Helia 29(45): 107-116.

Encheva, J., Christov, M., Shindrova, P., Drumeva, M. and Encheva, V., 2006. New sunflower restorer lines, developed by direct organogenesis method from interspecific cross Helianthus annuus L. (cv. Albena) $\times$ Helianthus salicifolius-desease resistance, combining ability. Journal of Genetic and Breeding 60(2): 77-84.

Faure, N., Serieys, H., Griveau, Y., Kann, F., Tersac, M. and Berville, A., 1998. Characterization of interspecific and intergeneric hybrids between cultivated sunflower $(H$. annuus L.) and distant species from Helianthus genus and other related genera. Proceedings of the Fourth European Conference on Sunflower Biotechnology. October, 20-23, Montpellier, France.

Henn, H.J., Wiongender, R. and Schnabl, H., 1998. Regeneration of fertile interspecific hybrids from protoplast fusions between Helianthus annuus L. and wild Helianthus species. Plant Cell Reports 18: 220-224.

Kräuter, R., Steinmetz, A. and Friedt, W., 1991. Efficient interspecific hybridization in the genus Helianthus via "embryo-rescue" and characterization of the hybrids. Theor. Appl. Genet. 82: 521-525.

Köhler, H.,. Brahm, L., Rocher, T. and Friedt, W., 1997. Anwendung molekulargenetischer Techniken in der Resistenzzuchtung bei der Sonnenblume (Helianthus annuus) [Application of molecular methods in breeding for disease resistance in sunflower (Helianthus annuus)]. Vortr. Pflanzenzuchtung 36: 47-50.

Köhler, H. and Friedt, W., 1999. Genetic variability as identified by AP-PCR and reaction to midstem infection of Sclerotinia sclerotiorum among interspecific sunflower (Helianthus annuus L.) hybrid progenies. Crop. Science 39(5): 1456-1463.

Lamkey, K. R. and Lee, M., 1993. Quantitative genetics, molecular markers, and plant improvement. In: B.C. Imrie and J.B. Hacker [eds.] Focused plant improvement: Towards responsible and sustainable agriculture. Proc. $10^{\text {th }}$ Australian Plant Breeding Australia pp. 104-115.

Mohan, G.S. and Seetharam, A., 2005. Studies on relationship among cultivated and wild sunflower through RAPD markers. Cytologia 70(3): 267-273.

Nei, M. and Li, W.H., 1979. Mathematical model for studying genetic variation in terms of restriction endonucleases. Proc. Natl. Acad. Sci. USA 76: 5269-5273.

Saftić-Panković, D., 2007. Application of molecular markers in sunflower breeding. Genetika 39(1): 1-11.

Seiler, G.J., Pomeroy, J.S. and Marinković, R., 1992. Valuable sunflower germplasm collected from the Northwestern United States. Helia 15(17): 1-6.

Schilling, E.E. and Heiser, C.B., 1981. Infrageneric classification of Helianthus (Compositae). Taxon 30: 393-403. 
Škorić, D., 1987. In : Progress report 1984-1986. FAO Subnetwork. Genetic evaluation and use of Helianthus wild species and their use in breeding programs [ed. D. Škorić]. FAO, Rome, Italy, 1: 17.

Škorić, D. and Rajčan, I., 1992. Breeding of Sclerotinia tolerance in sunflower. In: Proceedings of the $13^{\text {th }}$ International Sunflower Conference, Sept. 07-11, 1992, Pisa (Italy), Vol. I: 1257-1262.

Škorić, D., Atlagić, J., Marinković, R., Dozet, B. and Mihaljčević, M., 1995. In: FAO Working Group: Evaluation of wild Helianthus species, Progress Report 1994, July 25- 28, 1995, Bucharest (Romania) pp. 11-25.

Thompson, T.E., Zimmerman, D.C. and Rogers, C.E., 1981. Wild Helianthus as a genetic resource. Field Crops Res. 4: 333-343. 